Case Report

\title{
Clinical Phenotype in a Toddler with a Novel Heterozygous Mutation of the Vitamin D Receptor
}

\author{
Preneet Cheema Brar, ${ }^{1}$ Elena Dingle, ${ }^{1}$ John Pappas, ${ }^{2}$ and Manish Raisingani1 \\ ${ }^{1}$ Department of Pediatrics, Division of Pediatric Endocrinology and Diabetes, New York University School of Medicine, \\ New York, NY, USA \\ ${ }^{2}$ Department of Pediatrics, Clinical Genetics Services, New York University School of Medicine, New York, NY, USA
}

Correspondence should be addressed to Preneet Cheema Brar; preneet.brar@nyumc.org

Received 6 February 2017; Accepted 23 March 2017; Published 23 May 2017

Academic Editor: Mihail A. Boyanov

Copyright (c) 2017 Preneet Cheema Brar et al. This is an open access article distributed under the Creative Commons Attribution License, which permits unrestricted use, distribution, and reproduction in any medium, provided the original work is properly cited.

We present the clinical phenotype of a toddler who presented with vitamin D-resistant rickets, with one of the highest initial levels of alkaline phosphatase and parathyroid hormone (PTH) levels reported in the literature. The toddler had novel compound heterozygous mutations in the ligand-binding site of the vitamin $\mathrm{D}$ receptor and had an excellent response to calcitriol $(1,25(\mathrm{OH}) 2 \mathrm{D})$

\section{Background}

Hereditary vitamin D-resistant rickets (HVDRR) is an autosomal recessive disease caused by abnormality of the vitamin $\mathrm{D}$ receptor (VDR). Homozygous or compound heterozygous mutations of this gene result in the inability of VDR to regulate target genes even in the abundance of 1,25-dihydroxyvitamin $\mathrm{D}(1,25(\mathrm{OH}) 2 \mathrm{D} 3)$ which results in compensatory hyperparathyroidism with hypocalcaemia, hypophosphatemia, and osteopenia $[1,2]$.

Though true prevalence is not well established, there are no gender differences in the incidence, with reported cases being in consanguineous families from the Mediterranean and Middle East regions [3, 4].

There are two main functional domains in the VDR protein: DNA-binding domain (DBD) and ligand-binding domain (LBD). Mutations in the DBD prevent the VDR from binding to vitamin $\mathrm{D}$ response elements (VDREs) in target genes causing absolute resistance to $1,25(\mathrm{OH}) 2 \mathrm{D}$ resulting in a more severe clinical phenotype. Mutations in the LBD prevent binding of VDR to $1,25(\mathrm{OH}) 2 \mathrm{D}$ or interfere with VDR signaling [5,6]. Alopecia is a specific clinical manifestation of HVDRR and is usually associated with DBD mutations, though it is seen in some cases. In this report, we describe clinical manifestation of the two compound heterozygous mutations in the $\mathrm{DBD}$ and $\mathrm{LBD}$ domains, respectively.

\section{Case Report}

We present a 19-month-old Hispanic female toddler with poor interval growth. Though she was meeting her developmental milestones, her height and weight were below the third percentile with weight of $8.7 \mathrm{~kg}(<3 \%)$ and height of $75 \mathrm{~cm}(2 \%)$. She was a full-term, spontaneous vaginal delivery without complications during labor or pregnancy. She was the product of nonconsanguineous marriage. She was on no medications; there were no other siblings with failure to thrive. There was no history of malabsorptive conditions.

Her review of systems is negative for emesis, diarrhea, fever, appetite changes, swallowing abnormalities, respiratory symptoms, apnea, repeated acute illnesses, or frequent injuries. Her physical exam is significant for an alert, playful, developmentally appropriate child, small for her age. Her head/neck, cardiac, respiratory, gastrointestinal, genitourinary, musculoskeletal, and neurological exams were within normal limits. She had no evidence of dysmorphism and had no alopecia on exam. The laboratory testing at baseline included calcium of $7.6 \mathrm{mg} / \mathrm{dl}(8-10.4)$, alkaline phosphatase 


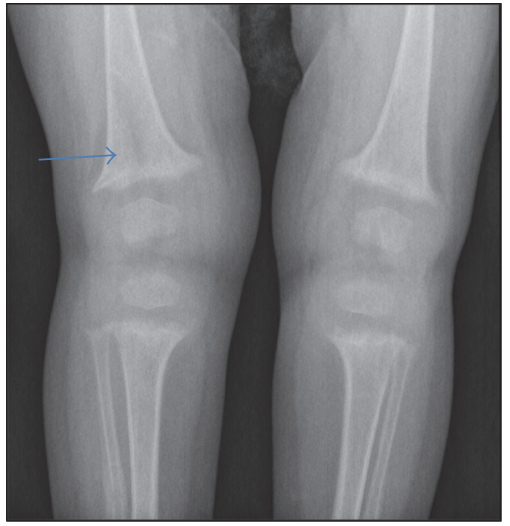

(a) Radiograph of the knees at initial presentation. AP radiograph of both knees. There is widening of the physes above the knee with splaying and fraying of the metaphyses. No fracture or dislocation is seen. Bones appear demineralized. Impression: findings compatible with rickets. The blue arrow points at the fraying at the end of the bones

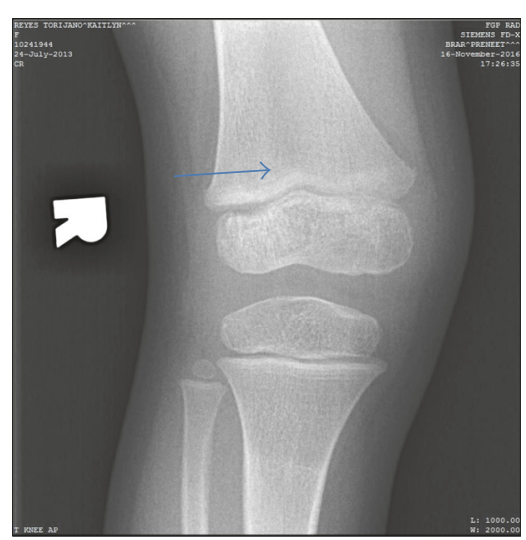

(b) Radiograph of the knee after RX at the age of 3 years. AP radiograph of the right knee. Healed rickets. Bones appear demineralized. No fractures or dislocation is seen. The blue arrow points at the fraying at the end of the bones of 2023 IU/L (25-100 adult reference in our lab, with $80 \%$ bone isoenzyme), PTH of $1115 \mathrm{pg} / \mathrm{ml}$ (14-72), phosphorus of $2.9 \mathrm{mg} / \mathrm{dl}(2.7-4.5), 25-\mathrm{OH}$ vitamin D3 of $14.2 \mathrm{ng} / \mathrm{ml}$ (30-100), and 1,25(OH)2 vitamin D3 of $505 \mathrm{pg} / \mathrm{ml}(19-79)$. The skeletal survey: Figure 1(a) shows metaphyseal fraying and cupping of the distal femur, proximal tibia, and fibula consistent with rickets. Figure 1(b) shows healing rickets. The toddler was started on $4000 \mathrm{IU}$ of ergocalciferol daily and $3 \mathrm{ml}$ of calcium glubionate TID ( $200 \mathrm{mg} /$ day; $23 \mathrm{mg} / \mathrm{kg} /$ day). 10 days later, her calcium went down to 7.3, and she received IV calcium ( $6 \mathrm{ml}$ q6h, $64 \mathrm{mg} / \mathrm{kg} /$ day). Her calcium normalized within 48 hours and she was continued on $64 \mathrm{mg} / \mathrm{kg} / \mathrm{day}$ of oral calcium and ergocalciferol dose of 2000 IU daily. Her calcium level was fluctuating between 7.7 and 8.3 (Table 1). At 21.5 months of age, she was started on calcitriol $0.5 \mathrm{mcg}$ $\mathrm{BID}$ as we suspected resistant rickets. Calcitriol was gradually increased up to the current dose of $8 \mathrm{mcg}$ BID. Her PTH and alkaline phosphatase were gradually trending down (Table 1). After 6 months of treatment on 8 mcg BID of calcitriol and $150-200 \mathrm{mg} /$ day of elemental calcium, she had a PTH of $300 \mathrm{pg} / \mathrm{ml}$ and calcium of $8.7 \mathrm{mg} / \mathrm{dl}$ and had early radiological signs of healing rickets and clinical improvement in gait. Calcium treatment was finally stopped at 29 months of age with healing of rickets (Table 1).

\section{Genetic Analysis}

Genomic DNA was isolated from peripheral blood samples of the patient. The VDR gene was amplified by polymerase chain reaction (PCR) and all exons of the coding region of the VDR gene were directly sequenced at the Baylor Miraca Genetics Laboratories. Direct sequence analysis of PCR products was performed in both forward and reverse directions using automated fluorescence dideoxy sequencing methods. There were two compound heterozygous mutations found in this patient. One of them was a heterogenous missense mutation of $\operatorname{Arg} 274$ (Arg274His) in exon 9 which changed the codon for arginine to histidine at amino acid 274. The second mutation was a heterogenous missense mutation of Arg73 (Arg73Glu) in exon 5 which changed the codon for arginine to glutamine at amino acid 73 . The sequence analysis also identified benign sequence variants: homozygous c.2T $>C$ (p.M1T) polymorphism in exon 4 and c.1056T $>$ C (p.I352I) variant in exon 11. Both parents were asymptomatic though parental analysis of the VDR sequence will be performed.

\section{Discussion}

Our toddler had a remarkable response to calcitriol, despite having one of the highest initial PTH $(1115.4 \mathrm{pg} / \mathrm{ml})$ and alkaline phosphatase (2023 IU/L) levels reported. Sequence analysis of the toddler's DNA revealed two compound heterozygous mutations in the VDR gene.

The clinical severity in case of LBD mutations depends on the affinity of VDR and varies from reduced affinity to $1,25(\mathrm{OH}) 2 \mathrm{D} 3$ to a total absence of binding to $1,25(\mathrm{OH}) 2 \mathrm{D} 3$. Amino acids 123-427 constitute the VDR LBD with R274 being the ligand-binding site located in helix $\mathrm{H} 5$ that makes contact with the $1 \alpha$-hydroxyl group of $1,25(\mathrm{OH}) 2 \mathrm{D} 3$ [7]. Mutant R274H is similar to mutant R274L and is characterized by 100 -fold less responsiveness to $1,25(\mathrm{OH}) 2 \mathrm{D} 3 \mathrm{com}$ pared to the wild-type VDR [3,4]. All previously reported patients with R274H and R274L were from Middle Eastern countries. Later, two case presentations of the homozygous mutant R274H were reported by Aljubeh et al. [4]. The clinical manifestation of these two patients with HVDRR was much more severe compared to our toddler. Both patients developed respiratory complications with one of them requiring 
TABLE 1: Metabolic parameters on diagnosis and during RX.

\begin{tabular}{|c|c|c|c|c|c|c|}
\hline $\begin{array}{l}\text { Time after } \\
\text { diagnosis } \\
\text { (weeks) }\end{array}$ & $\begin{array}{l}\text { Calcium } \\
(\mathrm{mg} / \mathrm{dl})\end{array}$ & $\begin{array}{c}\text { Alkaline } \\
\text { phosphatase } \\
\text { (IU/L) }\end{array}$ & $\begin{array}{c}\text { 25-OH vitamin } \\
\text { D2 } \\
(\mathrm{ng} / \mathrm{ml})\end{array}$ & $\begin{array}{c}1,25(\mathrm{OH}) \\
\text { vitamin D3 } \\
(\mathrm{pg} / \mathrm{ml})\end{array}$ & $\begin{array}{c}\text { PTH } \\
(\mathrm{pg} / \mathrm{ml})\end{array}$ & Calcium/creatinine ratio (urine) \\
\hline Baseline & 7.6 & 2023 & 14 & 505 & 1115 & 0.15 \\
\hline 2 weeks & 7.3 & 1579 & 31 & 901 & 764 & 0.06 \\
\hline 1 month & 7.8 & 1708 & 20 & 784 & 924 & 0.31 \\
\hline 1.5 months & 7.7 & 1879 & 44 & 1165 & 866 & 0.29 \\
\hline 2 months & 7.9 & 1579 & 36 & 901 & 901 & ND \\
\hline 3 months & 7.9 & 1686 & 40 & 959 & 959 & 0.12 \\
\hline 4 months & 8.8 & 1343 & 44 & 2064 & 437 & 0.17 \\
\hline 5 months & 8.2 & 848 & 41 & 1300 & 536 & 0.3 \\
\hline 8 months & 8.7 & 705 & 33 & $>600$ & 300 & ND \\
\hline 10 months & 9.5 & 662 & 36 & $>600$ & 147 & ND \\
\hline 12 months & 9.5 & 441 & 58 & $>600$ & 210 & ND \\
\hline 16 months & 9.4 & 287 & 45 & $>600$ & 76 & 0.06 \\
\hline 21 months & 9.7 & 180 & 43 & $>600$ & 35 & 0.06 \\
\hline
\end{tabular}

Metabolic parameters (reference values): calcium $=8-10.4 \mathrm{mg} / \mathrm{dl}$; alkaline phosphatase $=25-100 \mathrm{IU} / \mathrm{L}$ (adult reference in our lab, with $80 \%$ bone isoenzyme); $\mathrm{PTH}=14-72 \mathrm{pg} / \mathrm{ml} ; 25-\mathrm{OH}$ vitamin D2 = 30-100 ng $/ \mathrm{ml} ; 1,25(\mathrm{OH})$ vitamin D3 = 19-79 pg/ml. ND: not done.

oxygen supplementation. The first patient was initially started on oral calcium at the dose of $500-600 \mathrm{mg} / \mathrm{kg} / \mathrm{day}$ with a poor response. Both of them required high doses of IV calcium infusions $(90-200 \mathrm{mg} / \mathrm{kg} / \mathrm{day})$ for at least three months. Our toddler had a heterozygous mutation of $\mathrm{R} 274 \mathrm{H}$ which could explain her less severe presentation, although she had 10 times higher level of PTH and two times higher level of alkaline phosphatase compared to the two cases reported by Aljubeh et al. [4]

Our case has compound heterozygosity for the Arg274His and the Arg73Glu. The residue Arg73 is located at the tip of the second zinc finger of the intracellular vitamin D receptor and it is conserved in evolution. Hughes et al. (1988) reported on two sisters from consanguineous heterozygous and asymptomatic parents of a black Haitian origin. The described mutation resulted in an Arg70Gly substitution and a decreased affinity for DNA. The reported mutation is actually Arg73Gln (R73Q) based on corrected sequencing. In the functional cDNA analysis, Hughes et al. found decreased affinity of the expressed VDR mutant to $1,25(\mathrm{OH}) 2 \mathrm{D} 3$. Arginine at this position is critical for the interaction of receptor with DNA. The toddler in our case report had a compound heterozygous mutation that could explain her mild symptoms of HVDRR.

The cornerstone of treatment in HDVRR is to overcome the absent or reduced affinity of the ligand $1,25(\mathrm{OH}) 2 \mathrm{D} 3$ for the VDR using available formulations of $1,25(\mathrm{OH}) 2 \mathrm{D} 3$. In the previous report by Aljubeh et al., the dose of calcitriol was $10-15 \mathrm{mcg} /$ day [4] in addition to $150-600 \mathrm{mg} / \mathrm{kg} /$ day of IV elemental calcium. Our patient has sustained normal serum calcium on much higher calcitriol treatment $(24 \mathrm{mcg} / \mathrm{day})$ without the need for oral elemental calcium. As long as the urine is being monitored for hypercalciuria, normalization of the PTH is the mainstay of treatment. Healing of the rickets has been observed in some children with discontinuation of all therapy. This resolution of HDVRR may be the result of VDR-independent pathways of calcium absorption in the gut combined with effects of estrogens during puberty through upregulation of calcium transport protein 1 channels (CaT1) [8].

\section{Conclusion}

Our case illustrates compound heterozygous mutations in the VDR both in the hormone-binding and in the nuclearbinding site with a less severe presentation of rickets and a quick response to treatment with calcitriol and a short-term calcium requirement, despite having one of the highest initial PTH and alkaline phosphatase levels reported.

\section{Conflicts of Interest}

All authors have indicated they have no potential conflicts of interest to disclose.

\section{References}

[1] P. J. Malloy, J. W. Pike, and D. Feldman, “The vitamin D receptor and the syndrome of hereditary 1,25-dihydroxyvitamin Dresistant rickets," Endocrine Reviews, vol. 20, no. 2, pp. 156-188, 1999.

[2] D. Feldman and P. J Malloy, "Mutations in the vitamin D receptor and hereditary vitamin D-resistant," BoneKEy Reports, vol. 3, 2014.

[3] K. Kristjansson, A. R. Rut, M. Hewison, J. L. H. O’Riordan, and M. R. Hughes, "Two mutations in the hormone binding domain of the vitamin $\mathrm{D}$ receptor cause tissue resistance to 1,25 dihydroxyvitamin D3," Journal of Clinical Investigation, vol. 92, no. 1, pp. 12-16, 1993. 
[4] J. M. Aljubeh, J. Wang, S. S. Al-Remeithi, P. J. Malloy, and D. Feldman, "Report of two unrelated patients with hereditary vitamin D resistant rickets due to the same novel mutation in the vitamin D receptor," Journal of Pediatric Endocrinology and Metabolism, vol. 24, no. 9-10, pp. 793-799, 2011.

[5] N. S. Ma, P. J. Malloy, P. Pitukcheewanont, D. Dreimane, M. E. Geffner, and D. Feldman, "Hereditary vitamin D resistant rickets: Identification of a novel splice site mutation in the vitamin $\mathrm{D}$ receptor gene and successful treatment with oral calcium therapy," Bone, vol. 45, no. 4, pp. 743-746, 2009.

[6] P. J. Malloy and D. Feldman, "Molecular defects in the vitamin D receptor associated with hereditary 1,25-dihydroxyvitamin D resistant rickets," in Vitamin D: Physiology, Molecular Biology, and Clinical Applications, M. F. Holick, Ed., pp. 691-714, Humana Press, NJ, USA, 2010.

[7] N. Rochel, J. M. Wurtz, A. Mitschler, B. Klaholz, and D. Moras, "The crystal structure of the nuclear receptor for vitamin D bound to its natural ligand," Molecular Cell, vol. 5, no. 1, pp. 173$179,2000$.

[8] S. J. Van Cromphaut, K. Rummens, I. Stockmans et al., "Intestinal Calcium Transporter Genes Are Upregulated by Estrogens and the Reproductive Cycle Through Vitamin D Receptor-Independent Mechanisms," Journal of Bone and Mineral Research, vol. 18, no. 10, pp. 1725-1736, 2003. 


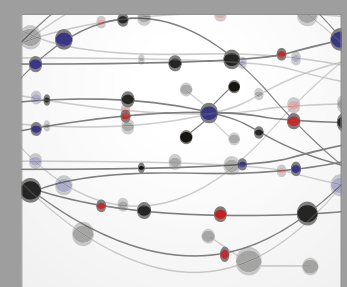

The Scientific World Journal
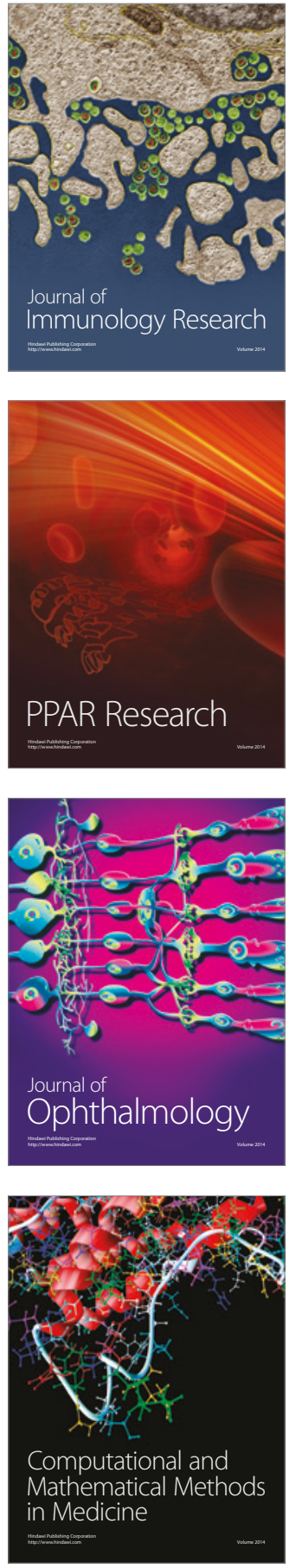

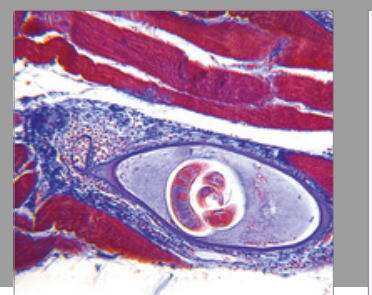

Gastroenterology Research and Practice
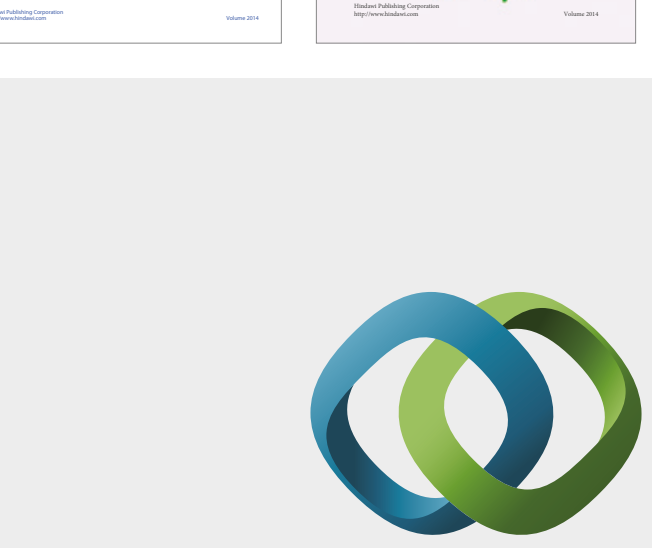

\section{Hindawi}

Submit your manuscripts at

https://www.hindawi.com
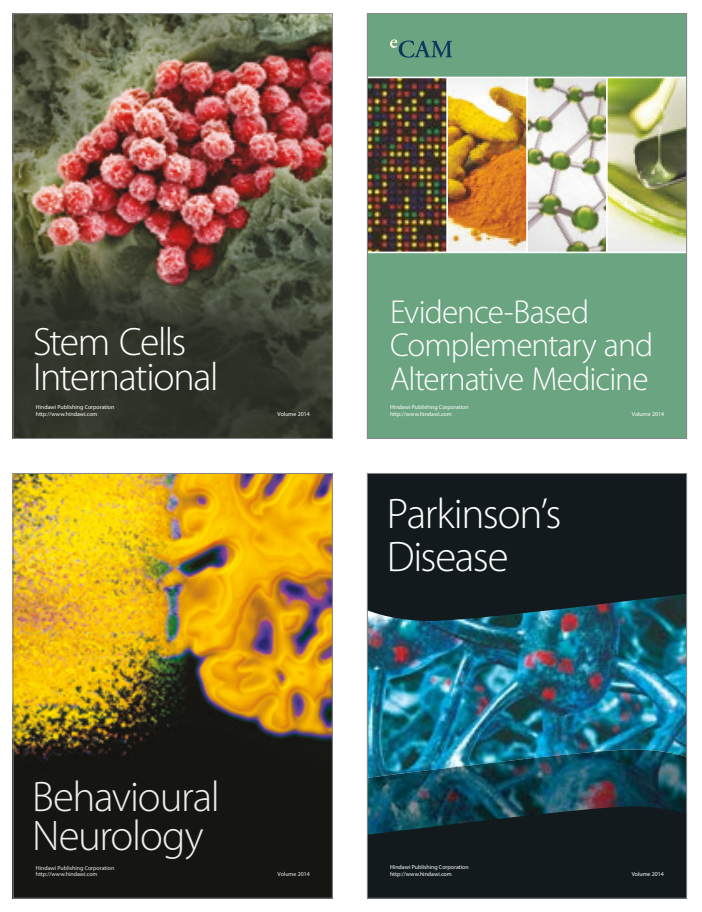
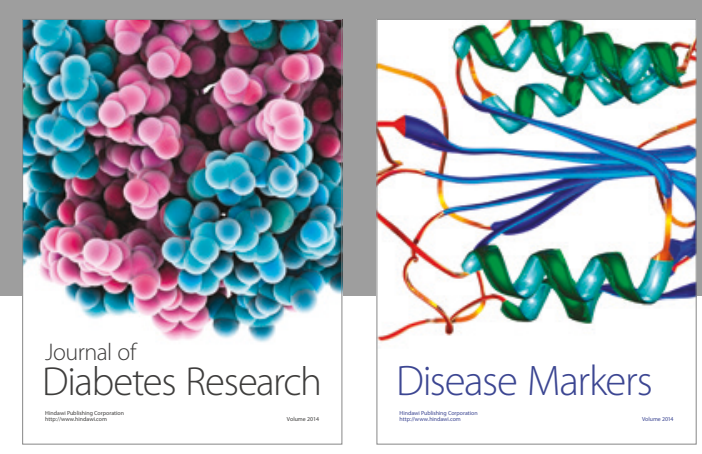

Disease Markers
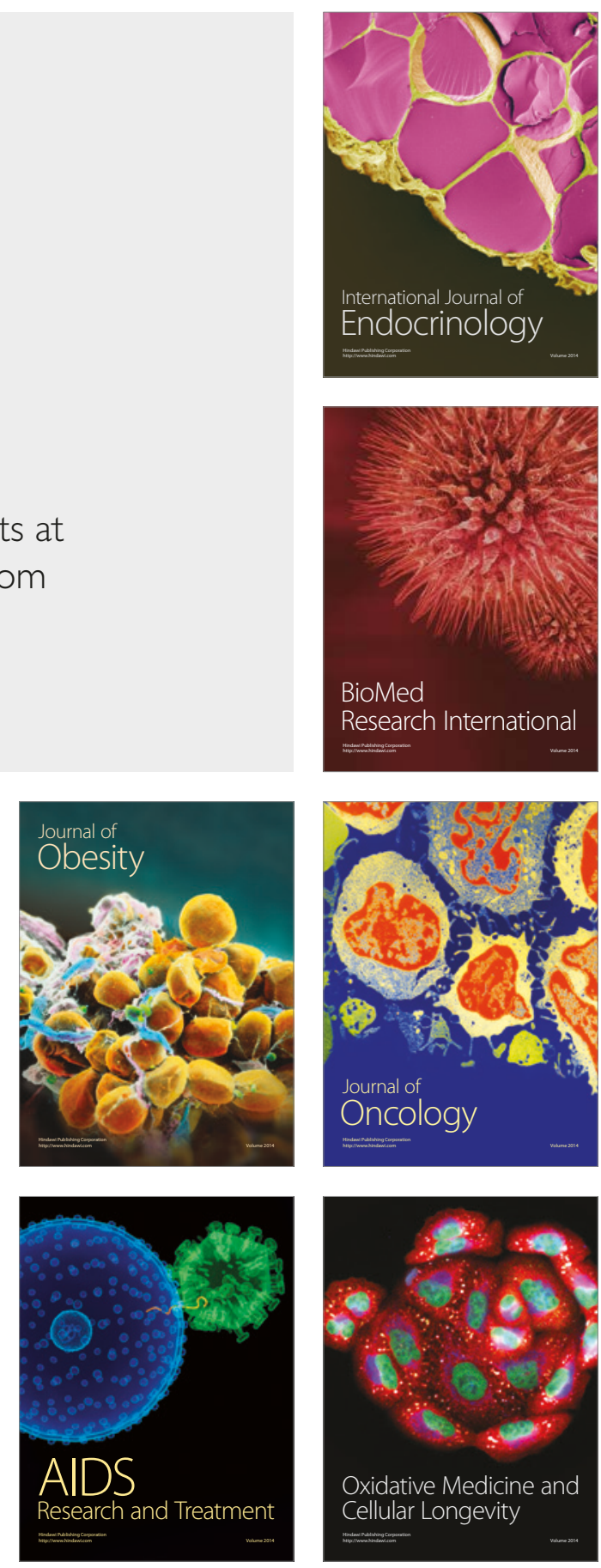